\title{
Recent activity of Nyiragongo (Democratic Republic of Congo): new insights from field observations and numerical modeling
}

P.-Y. Burgi ${ }^{1 *}$, G. Boudoire ${ }^{2}$, F. Rufino ${ }^{3}$, K. Karume ${ }^{4}, \quad$ and D. Tedesco ${ }^{3}$

${ }^{1}$ IT Department, University of Geneva, 1211 Genève, Switzerland.

${ }^{2}$ Laboratoire Magmas et Volcans, UCA, CNRS, IRD, OPGC, 63178 Aubière, France.

${ }^{3}$ DISTABIF, Second University of Naples, 81100 Caserta, Italy.

${ }^{4}$ Observatoire Volcanologique de Goma, Goma, Democratic Republic of Congo

* Corresponding author: Pierre-Yves Burgi (pierre-yves.burgi@unige.ch)

Key Points:

- Current eruptive activity at Nyiragongo mirrors that observed in 1970-1972 and 1994-1995

- Activity forecasting is backed up by simulations of a mathematical model

- Based on the Forecast Failure Model, a new lava lake drainage in the March 2024 November 2027 interval could be a possible scenario 


\begin{abstract}
Nyiragongo volcano is known for its active lava lake and for major socio-economic issues which arise from future possible eruptive events having major impacts on the growing community living in the Virunga region. The 2020 field expedition inside the summit crater has allowed the collection of unprecedented field observations to state on the current eruptive activity. Since the intra-crater event of February 2016, the crater floor level has been rising much faster than during the 2010-2016 period. The current activity is reminiscent of the 1970-1972 and 1994-1995 periods preceding the lava lake drainage events in 1977 and 2002, respectively. Numerical simulations, successfully validated with data over the past 30 years of data, show that the rising of the crater floor 1 could slow down in the next months/years and reach a critical equilibrium. Based on the past eruptive history and on the current activity , a flank eruption in the March 2024 - November 2027 interval could be a possible scenario .
\end{abstract}

\title{
Plain Language Summary
}

Nyiragongo volcano hosts within its crater the world's largest continuously active lava lake within its crater. This constitutes major socio-economic issues which arise from future possible eruptive events having a catastrophic impacts to the Virunga volcanic region's growing community within the Democratic Republic of Congo (DRC) and Rwanda, particularly the cities of Goma and Gisenyi with about 1.5 million people living at its foot. The 2020 field expedition inside the summit crater has allowed the collection of unprecedented field observations to state on the current eruptive activity. Since a new and unusual eruptive event occurred on February 29, 2016, the crater floor level has been rising much faster than during the 2010-2016 period. The current activity is reminiscent of the 1970-1972 and 1994-1995 periods preceding the lava lake drainage events in 1977 and 2002, respectively. Numerical simulations, successfully validated with data over the past 30 years of data, show that the rising of the crater floor could slow down in the next months/years and reach a precarious balance. Based on the past eruptive history and on the current activity, we stress that a flank eruption in the March 2024 - November 2027 interval could be a possible scenario .

\section{Introduction}

Increasing understanding of magma transfer from Earth mantle to surface is a challenging goal involving the need of a correct understanding of the evolution in time and space of eruptive activities (Poland et al., 2012; Boudoire et al., 2019). It is even more fundamental in (very) low- to middle-income countries where volcanic lands tend to favor socio-economic development (Shoji \& Takahashi, 2002). Unfortunately, 
environmental, economic and/or political conditions are often a hindrance to the development of adequate monitoring strategies. The Virunga volcanic province, on the Eastern African Rift (EARS), is a perfect example of such a place (Fig. 1a). The site needs a greater understanding and monitoring of the volcanic activity, which is as important as the challenge to face major implications arising from the densely populated areas in the vicinity of the volcano (Tedesco, 2002/2003; Tedesco et al., 2010; Spampinato et al., 2013; Cuoco et al., 2013a, Cuoco et al., 2013b; Balagizi et al., 2018). Among the 8 volcanoes hosted in the province, Mount Nyiragongo hosts within its crater the world's largest continuously active lava lake (Durieux, 2002/2003). In the last five decades, Nyiragongo's lava lake was drained catastrophically twice, in 1977 and 2002 (Tazieff, 1984; Tedesco et al., 2007) from flank eruptions. These eruptions have raised important civil protection issues (400-1,500 fatalities in 1977; 250 in 2002; Tedesco et al, 2007). During the last event, the lava flowed within the c ity of Goma (Fig. 1a) and caused major socio-economic disruption by leaving 120,000 people homeless (Baxter et al., 2002/2003; Tedesco et al, 2007) and destroying more than $80 \%$ of the economic infrastructure.

The sequential increase in lava lake volume and rapid fissure eruptions are likely responsible for the peculiar morphology of the crater (Tazieff, 1984; Durieux, 2002/2003). Its current morphology is set by three distinct volcanic platforms: P1 ( 1977 crater floor), P2 (1995-2002), and P3 (2002 to present) (Fig. 1). On February 29, 2016, the relative equilibrium between magma feeding and convection of the lava lake, which has characterized the volcanic activity after the 2002 eruption (Fig. 1b), was disrupted by the opening of an intra-crater fracture on the most eastern side of the crater (Balagizi et al., 2016; Valade et al., 2018). The fracture favored the appearance and growth of a spatter cone. On February 2017, the spatter cone was $30 \mathrm{~m}$ high and $70 \mathrm{~m}$ large at its base (Fig. 1c). Its activity contributed to raise the level of P3 by successive lava flows invading the platform and modifying the dynamics of the whole volcanic system by pouring several hundred millions of cubic meters of lava into the lava lake (Burgi et al., 2018). In February 2020, three years later, the P3 level has risen by more than $100 \mathrm{~m}$ (Fig. 1d), about three times faster than during the period 2010-2016. Such a fast increase is a putative indication of a change in the regime, which dominated the 2002-2016 eruptive phase. The paper aims to use the field observations of the crater floor level together with numerical model to decipher magma processes and suggest (new) monitoring strategies, in particular in the place where deploying and maintaining instrumental networks is highly challenging.

\section{Field observations and measurements}

We performed a field expedition inside the summit crater from February 10 to 19, 2020. During this field trip , a comprehensive series of field observations (Supplementary Text S1) were fulfilled 
to document the physical configuration of the summit active crater and the rate of magmatic activity within the crater. Attention was focused on four peculiar features of the eruptive activity: the spatter cone, the lava fall (the cascade of lava) fed from the spatter cone and pouring into the lava lake, the lava lake itself and two active lava ponds flowing in the northern part of the crater (Fig. 1e).

\subsection{Spatter Cone}

The spatter cone is $45-50 \mathrm{~m}$ high and about $100 \mathrm{~m}$ large at its base. It consists of a tilted "initial" part $\left(\sim 32^{\circ}\right)$ for about half of the height and becomes sub-vertical near the top (Fig. 1d). On the northern side of the spatter cone an elongated mound is piling up from spattering. At the time of observations this mound culminated at a height of $17 \mathrm{~m}$ and gently sloping over $80 \mathrm{~m}$. A continuous stirring of lava was visible in the U-shaped open vent (Fig. 1e). Lava flows continuously expanded out at the base of the cone and poured into the lava lake through an underground tunnel. Intermittent effusive activity from the summit of the cone since its formation in 2016 (Valade et al., 2018) resulted in piling up lavas around and filling P3 up to the point of reaching P2 and overflowing an area of about $16,000 \mathrm{~m}^{2}$ (Fig. 1d). This new morphology makes it possible to access P3 and thus allows an easy access to the lava lake banks. 

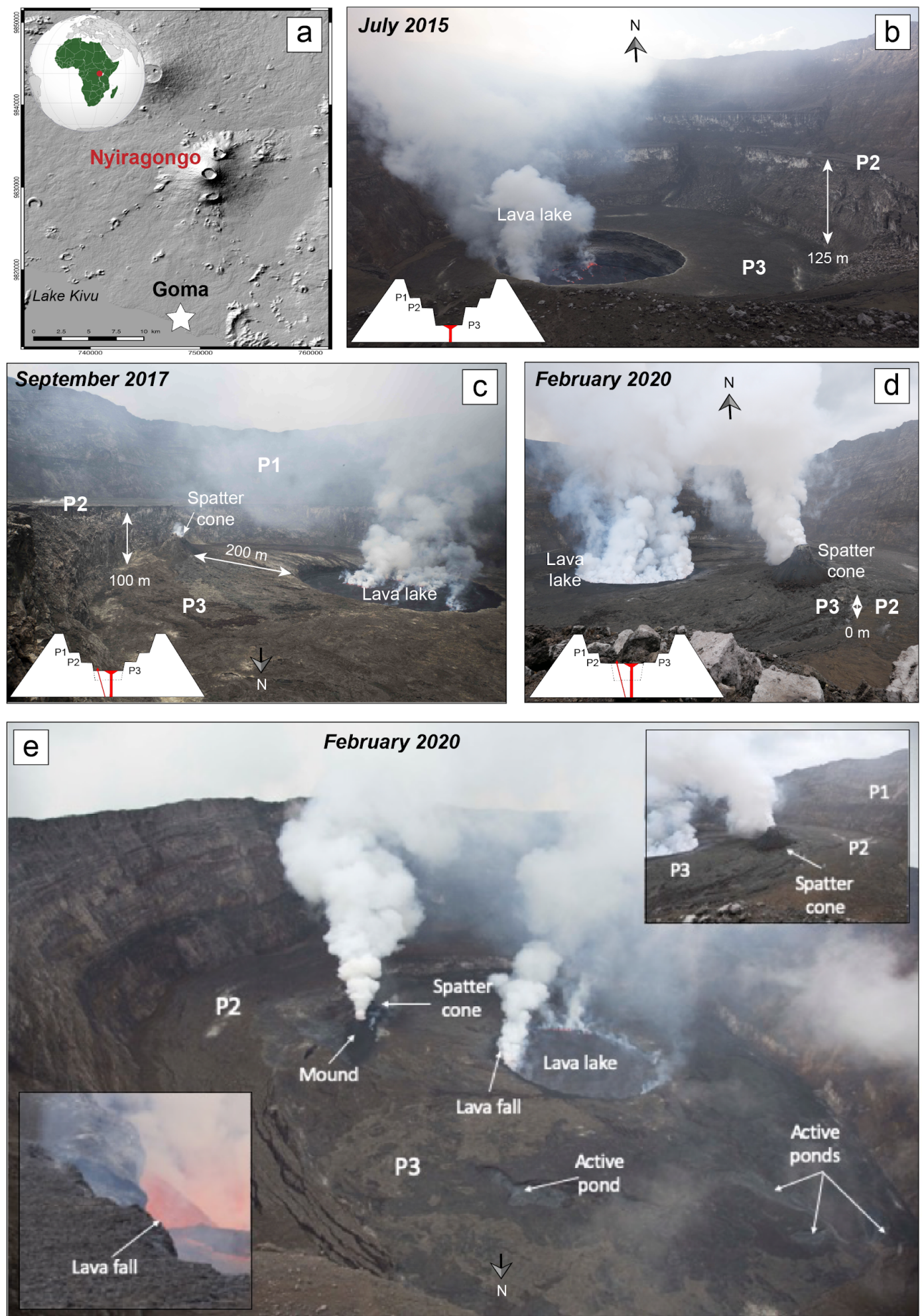

Figure 1. (a) Location of the Nyiragongo volcano and the $\mathrm{c}$ ity of Goma. Evolution of the morphology of the summit crater from (b) July 2015 to (c) September 2017 (active spatter cone since February 29, 2016) to (d) February 2020, (e) General view of the summit crater of Nyiragongo crater during our field mission on February 2020, which shows the main features of the volcanic activity described in this study. P1, 
P2, P3 refer to the first, second and third platforms, respectively. They are represented in the schematic cross-section. Pictures were taken by the first author.

\subsection{Lava fall}

A lava tunnel of about $180 \mathrm{~m}$ length with a slope of $7^{\circ}$ connects the active spatter cone to the eastern rim of the lava lake. At the end of this tunnel, the lava cascades from a height of 1-2 $\mathrm{m}$, depending on the lake level, into the lava lake . The outflow is difficult to precisely estimate due to the intense degassing and lack of visibility . However, based on the rare sequences of images of the lava fall captured with a standard camera (Supplementary Video 1), we can estimate a maximum surface velocity of $3 \mathrm{~m} / \mathrm{s}$. Assuming a semi-circular channel of radius $r \quad 1 \mathrm{~m}$ (visual estimation), and the ground slope angle $\alpha=$ $7^{\circ}$, we apply a modified Jeffreys' equation to estimate a volumetric lava flux of $4 \mathrm{~m}^{3} / \mathrm{s}$ (Supplementary Text S2; Jeffreys, 1925; Lev \& James, 2014). This value is in the range of volumetric flow rates calculated for pahoehoe lava (Rowland and Walker, 1990; Gregg 2017) and fits also with those reported for lava tubes of similar geometry (Melnik, 2017).

\subsection{Lava lake}

The lava lake preserves its slightly elliptical shape with the long E-W axis measuring approximately 230 $\mathrm{m}$, and $210 \mathrm{~m}$ the N-S axis , for a total surface area of approximately $40,000 \mathrm{~m}^{2}$. These values are about 10\% smaller than those reported by Burgi et al. (2018) for September 2017 and by Barrière et al. (2019) for March 2018. Similarly, these values do not follow the linear progression that has taken place since the reappearance of the lava lake in 2002 (Burgi et al., 2014). Moreover, the position of the lava lake eastern rim has shifted towards the South-West by about $50 \mathrm{~m}$ between 2007 and 2015, and about $20 \mathrm{~m}$ towards the North-East between 2015 and 2020 (Fig. 2). Since September 2017, concomitantly with the lava lake level, P3 has risen by more than $100 \mathrm{~m}$. In February 2020, the level difference between P2 and P3 was in the range $0 \quad-25 \quad \mathrm{~m}$, with an overlapping of P2 and P3 around the spatter cone and the maximum measured in the western part of the crater . This fast evolution of the crater floor elevation is not unusual at Nyiragongo (Burgi et al., 2014). It is striking to note that a similar behavior was observed in the years preceding the complete drainage of the lava lake in both 1977 and 2002 events, with 3 phases $(\boldsymbol{\varphi} 1, \boldsymbol{\varphi} 2$ and $\varphi 3$ on Fig. 2e). A first phase ( $\boldsymbol{\varphi} 1)$ with a certain stabilization of the crater floor level between -400 and $-300 \mathrm{~m}$ (relative to the crater rim), observed in 1962-1970, 1985-1994 and 2010-2016. A second phase ( $\boldsymbol{\varphi} 2)$ of fast increase of the crater floor level was observed in 1970-1972, 1994-1995 and since 2016. Interestingly, these increases marked a change in the volcanic activity of Nyiragongo. On March 1971, the presence of vents emitting thick vapor and gaseous plumes were reported (Denaeyer, 1973; Durieux, 2002/2003), when no significant activity was observed before. In 
1994 and 2016, intra-crater eruptive actvitity started (Tedesco, 2002/2003; Burgi et al., 2018). A final phase $(\varphi 3)$ with the crater floor elevation reaching a plateau between -150 and -250 $\mathrm{m}$ (relative to the crater rim) occurring in the years preceding its complete drainage by flank eruption and lasting respectively from 1972 to 1977 and 1995 to 2002.
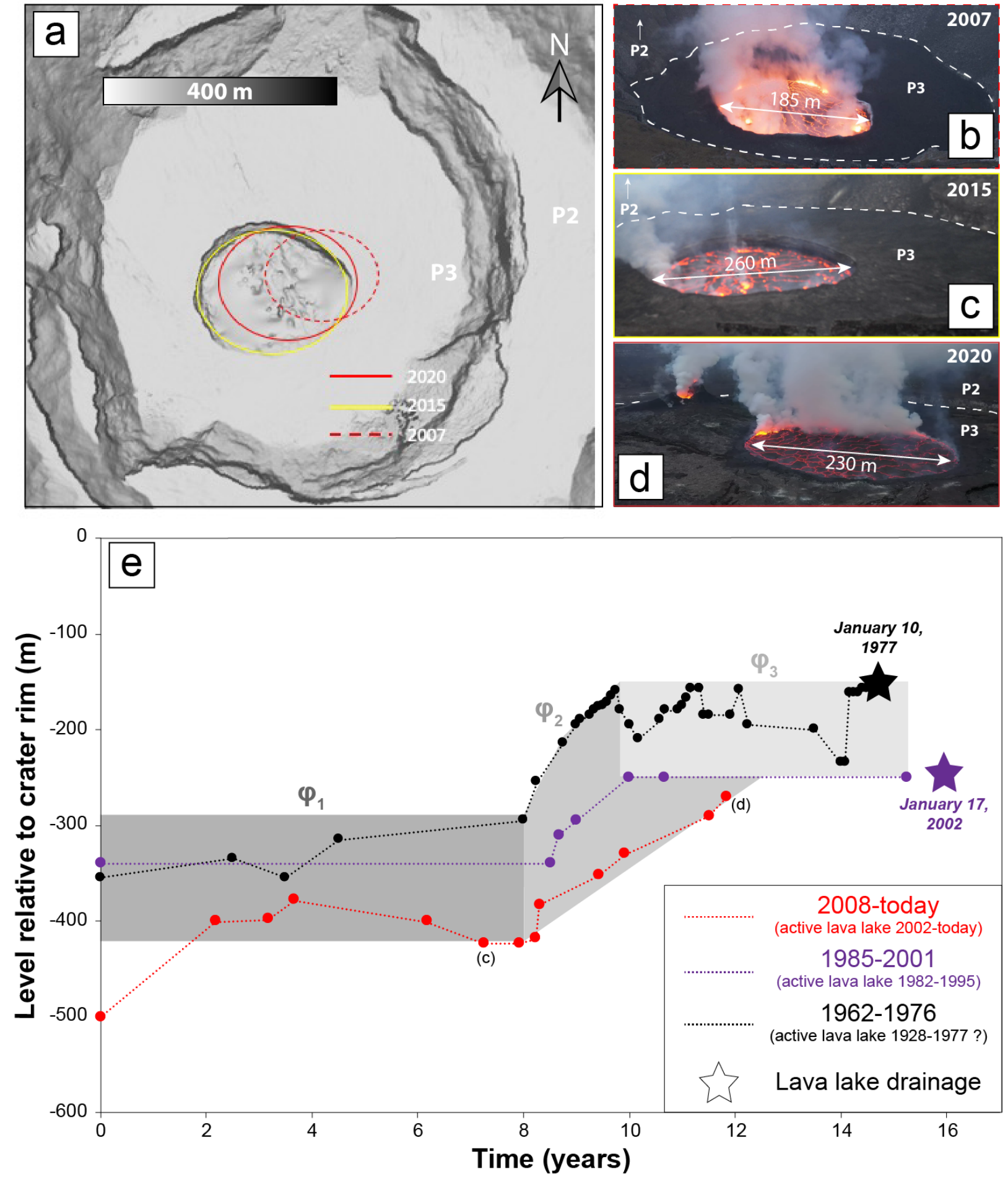
Figure 2. (a) Digital Elevation Model of the crater based on June 2015 field measurements, with the $p$ ositions of the lava lake rims in 2007 (dotted red circle), 2015 (yellow circle) and 2020 (red circle). Pictures (from first author) of P3 levels $\quad$ in (b) 2007, (c) 2015, and (d) 2020. $\quad$ (e) In c omparative progression of the level of the crater floor for three periods, two of them (1962-1976 and 1985-2001) have resulted in the complete drainage of the lava lake in 1977 and 2002, respectively (cf. stars). $\boldsymbol{\varphi} 1, \boldsymbol{\varphi} 2$ and $\boldsymbol{\varphi} 3$ (and corresponding filled grey shapes) are the three distinct periods preceding the last lava lake drainage (see text for explanation), with (c) and (d) indicating the level of the lake in 2015 and 2020, respectively.

\subsection{Lava rises and pits}

In the NW part of P3, about $500 \mathrm{~m}$ away from the spatter cone and $25 \mathrm{~m}$ beneath its basis, several tunneled" active lava flows form lava-rises and small ponds (Supplementary Fig. S1), which have the characteristics of lava-rise pits (Walker, 1991). These ponds are fed by tunnels starting from the spatter cone as testified by the presence of many skylights. The largest pond, oriented NE-SW, is $80 \mathrm{~m}$ long and about 25-30 m wide, and located 450 to the West of the lava lake. The smallest one oriented E-W, is $50 \mathrm{~m}$ in length and $20 \mathrm{~m}$ wide, and located $200 \mathrm{~m}$ North of the lake. Driven by slow and non-convective movements, lava flows from these two ponds into the lava lake. The entry points within the lava lake are observable when the level of the lake slightly decreases after degassing phases. The flux of these two inflows is estimated at $0.015 \mathrm{~m}^{3} / \mathrm{s}$ on average (Supplementary Text S2). They represent only a secondary feeding compared to the lava fall in the eastern part, which is directly connected to the spatter cone.

\section{Modeling and discussion}

The intra-crater fracture of February 29, 2016 marked an important break in the eruptive activity of Nyiragongo volcano (Burgi et al., 2018). Coupling field observations with numerical modeling could shed new light on the evolution of the magmatic activity and its impacts on the morphology of the summit crater.

\subsection{Magma flux modeling}

Burgi et al. (2014) developed a model based on magmastatic parameters to account for the flux of fresh magma required to keep the lava lake in a molten state. This model takes into consideration a bidirectional magma flow in a constrained system composed of (i) the lava lake whose geometry is calculated assuming an inverted shaped cone, connected through a vertical 
conduit taken as cylindrical; (ii) a magmatic reservoir whose geometry is still unknown. Within this model, the driving force that generates the convection is linked to a contrast of density, increasing for degassed and colder material emerging at the top of the lava lake. This model successfully reproduces over 30 years of field data of the lava lake level evolution, covering the periods 1982-1995, 2002-2011 and beyond (Burgi et al., 2014), including the two periods during which the lava lake was present (Tazieff, 1984; Durieux, 2002/2003). After the beginning of the intra-crater eruption of February 2016, the model has been revised to take into account the volumes of lava emitted by the spatter cone, and the proportion of lava flowing into the lava lake with respect to that flooding on P3 (Burgi et al., 2018), t ,

$\frac{d}{d t} V_{i n}=Q_{m o}+\phi Q_{v}$

where $Q_{v}$ is the ascending volume lava flow discharging into the dike feeding the spatter cone open fracture, $\phi$ is the proportion of this lava cascading back into the lava lake, $Q_{m o}$ is the volume flow rate needed to keep the lava lake in a molten state (proportional to the lava lake surface). $V_{i n}$ is the volume of degassed and cooled lava recycled in the lava lake that sinks into the shallow reservoir and increase its pressure through the buoyancy force

$F_{\text {in }}=f\left(V_{\text {in }}\right) \Delta \rho g V_{\text {in }}$

where the product $f\left(V_{i n}\right) \Delta \rho$ represents the "effective" density difference contributing to buoyancy, with $f($.) a regulatory fluidic function (Burgi et al., 2014), and $\Delta \rho$ the density difference between degassed (descending) and gas-rich (ascending) magma. In turn, the overpressure controls the lava lake level evolution (and thus the P3 level by lava lake overflows), and its volume $V_{l}$,

$\frac{d}{d t} V_{l}=Q-Q_{m o}-Q_{P 3}$

where $\mathrm{Q}$ is the total ascending volume flow in the vertical conduit between the shallow magmatic reservoir and the bottom of the lava lake, determined by Poiseuille's law (e.g., Bansal, 2010), and $Q_{P 3}$ the part accumulating on $\mathrm{P} 3$. . To get the best fit of the elevation of the crater floor during the past years, $\mathrm{t}$ he model requires that in average $96 \%$ of the lava emitted by the spatter cone has to flow into the lava lake.

(Fig. 3a). The remaining part flows on P3, and contributes to its elevation 
(about 40 m between February 2016 and February 2020). Similarly, our field observations provide evidence that almost all the lava emitted from the spatter cone discharges inside the lava lake through (i) the lava fall $\left(4 \mathrm{~m}^{3} / \mathrm{s}\right)$ and (ii) the lava-rises $\quad\left(0.015 \mathrm{~m}^{3} / \mathrm{s}\right) \quad$. The model highlights that the amount of lava pouring into the lava lake from the spatter cone is crucial to explain the fast increase of its elevation since 2016. In the case where no intra-crater eruption has developed, a much slower progression of the lava lake level is expected (dashed blue line on Fig. 3a) as observed in 2010-2016 but also on 1962-1970 and 1985-1994 ( $\boldsymbol{\varphi} 1$ on Fig. 2e).

By using the equations set for magma propagation through dikes (Gonnermann \& Taisne, 2015; Gudmundsson, 2016), the evolution of the volumetric magma flux feeding the spatter cone since the opening of the intra-crater fracture (possibly due to higher input of fresh magma which triggered a dike propagation) on February 29, 2016 may also be simulated (Fig. 3b). The determinant factors in these calculations are the overpressure in the magmatic reservoir feeding the dike, and the length of the dike (Traversa et al., 2010). In our case, the volumetric magma flux results from a magmastatic equilibrium between (i) the pressure of the shallow reservoir that is dependent on the accumulation of sinking degassed magma that increases the buoyancy force (Eq. 2) and (ii) the spatter cone elevation that represents the top of the dike and which increases with P3 level. Consequently, in our model, both the overpressure and length of the dike increase in time. Our simulation shows that the volumetric magma flux rate feeding the spatter cone is expected to vary between 2 and $6 \mathrm{~m}^{3} / \mathrm{s}$ in time (Fig. 3b). It is fully consistent with our estimation of $4 \mathrm{~m}^{3} / \mathrm{s}$ made during the February 2020 field expedition. However, this flux might have been much higher in an early phase of the spatter cone (Valade et al, 2018), and the curve in Fig. 3b represents a levelling of the peak activity values.

\subsection{Implications for the morphology of the summit crater}

Between 2017 and 2020, the crater floor quickly filled as lava flows piled up to almost $100 \mathrm{~m}$ high ( $\boldsymbol{\varphi} 2$ on Fig. 2e). This is three times more than what was observed between 2010 and 2016 ( $\boldsymbol{\varphi} 1$ on Fig. 2e). Knowing that the average diameter of P3 is $800 \mathrm{~m}$ (and did not change significantly between 2017 and 2020) the increase of the level of P3, including the lava lake, represents a lava input of about 50 $\mathrm{Mm}^{3}$, which in turn, corresponds to an average excess volumetric magma flux of $0.6 \mathrm{~m}^{3} / \mathrm{s}$ in the 2017 2020 period. Together with the $0.6-3.5 \mathrm{~m}^{3} / \mathrm{s}$ magma flux necessary to keep the lava lake in melted state (Burgi et al., 2014), we estimate that the current volumetric magma flux at Nyiragongo falls in the range $1.2-4.1 \mathrm{~m}^{3} / \mathrm{s}$, i.e. $0.04-0.13 \mathrm{~km}^{3} / \mathrm{yr}$. This volumetric magma flux is comparable with values reported for 
other lava lakes as at Kilauea (0.02-0.28 km³/yr; Dvorak and Dzurisin, 1993; Anderson and Poland, 2016) and Masaya (0.13-0.25 km³/yr; Zurek et al., 2019).

In this study, we estimated a maximal volumetric magma flux of $4 \mathrm{~m}^{3} / \mathrm{s}$ from the spatter cone during our stay. This magma flux feeding the spatter cone is expected to impact the dynamics of the lava lake by decreasing the upward feeding rate $\left(0.6-3.5 \mathrm{~m}^{3} / \mathrm{s}\right)$ necessary to keep it in a molten state (both the lava lake and the dike being fed by the same shallow magma reservoir; Burgi et al., 2018). A natural consequence would be a decrease of the size of the lava lake to compensate the heat lost from the surface by radiation and convection. This effect is observed between 2015 and 2020 (Fig. 2a). The eruptive activity of the spatter cone could also have an impact on the position of the lava lake. The surface motion of the lava lake is thought dominantly radial with a hot western zone (upwelling region) and a cooler eastern area (Spampinato et al., 2013; Lev et al., 2019) that may have triggered the westward shift observed between 2007 and 2015 (Fig. 2a). However, it is possible that the development of the spatter cone in the eastern part of the crater in February 2016 has contributed to inverting the displacement of the lava lake between 2015 and 2020 (Fig. 2a). If the volumetric magma flux does not change, our numerical simulation predicts that the lava will overflow entirely P2 by February 2021. In the longer term, if no tectonic and/or magmatic event breaks the current magmastatic equilibrium, our simulation anticipates that (i) the eruptive activity of the spatter cone should progressively decrease until its total inactivity by the first quarter of 2022 (Fig. 3b) and (ii) the overpressure in the shallow magma chamber would plateau at 19 $\mathrm{MPa}$. This value is in the range of those (15-20 MPa) reported at Kilauea during the 2018 rift zone eruption (Anderson et al., 2019). According to our model, by 2025 , the spatter cone will have discharged $600 \mathrm{Mm}^{3}$ of lava in the lava lake and about $20 \mathrm{Mm}^{3} \quad$ on $\mathrm{P} 3, \quad$ contributing to $50 \mathrm{~m}$ on the level increase since February 2016 (in complement to the lava lake overflows). In turn, the elevation of the lava lake should stabilize (and even slightly decrease) between -250 and -260 $\mathrm{m}$ (relative to the crater rim) in the next few years (Fig. 3a). A similar scenario was observed in 1972-1977 and 1995-2002 ( $\boldsymbol{\varphi} 3$ on Fig. 2e), i.e. in the years following a fast increase of the elevation of the lava lake and preceding its complete drainage . By the first quarter of 2025, the lava lake should contain about $16 \mathrm{Mm}^{3}$ for a total of $2 \mathrm{~km}^{3}$ of intruded material beneath the edifice that has been accumulating since 2002. 

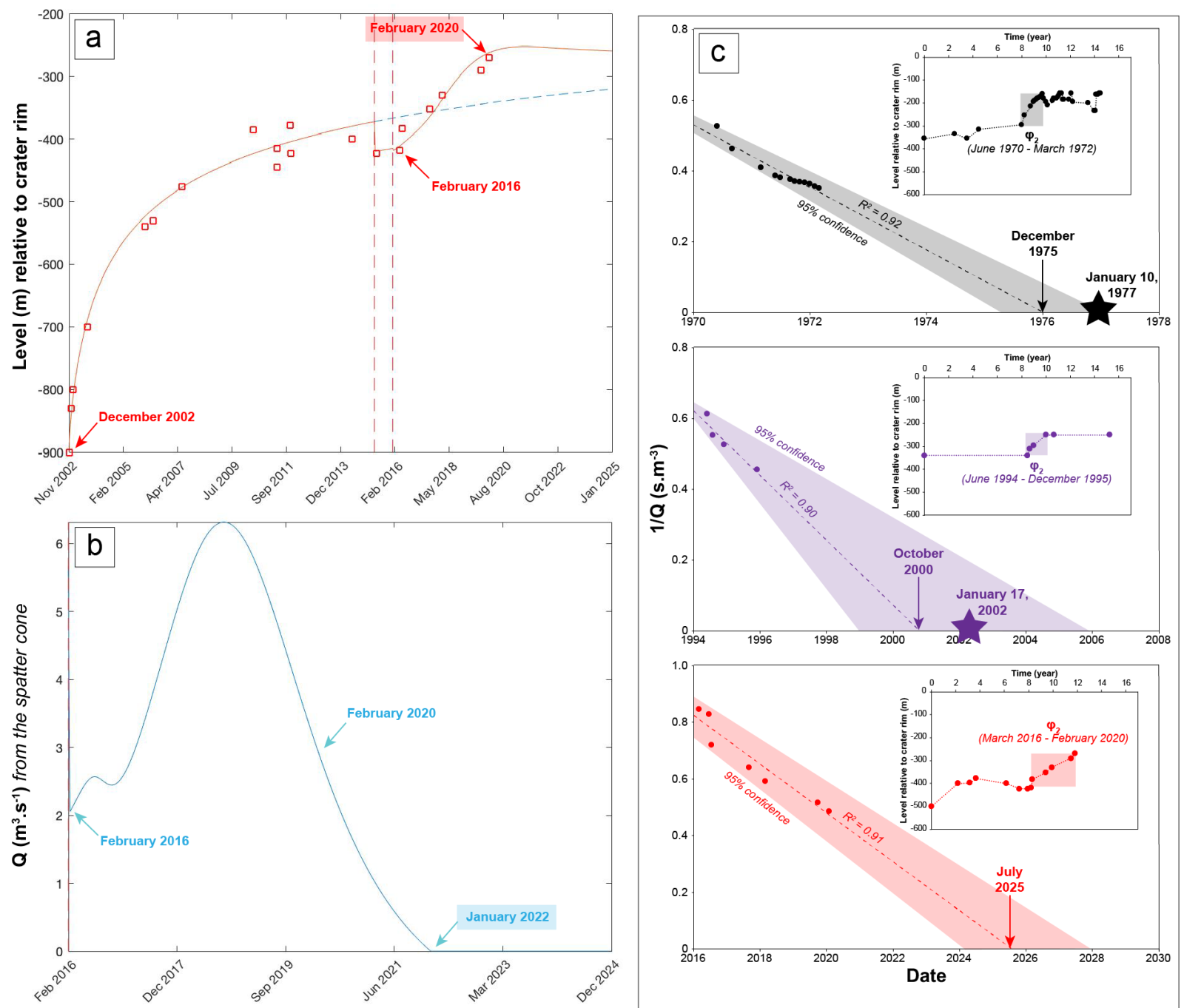

Figure 3. (a) Model for the evolution of the lava lake level from November 2002 to February 2025. The squares stand for the field measurements. The solid curve is the best fit obtained by numerical resolution

. Parameters as in Burgi et al. (2018), except $\phi=0.96$ and a density parameter (c $(\phi))$ in $\mathrm{f}($.$) , set to$ $65 \mathrm{~kg} / \mathrm{m} 3$. The dashed curve is the fit corresponding to the case without the dike event $\left(Q_{v}=0\right.$ in Eq. 1). The first and second vertical dashed lines indicate the time of a lava lake level drop preceding the dike event and the moment of the vent eruption, respectively (b) Modeled evolution of the average volumetric magma flux of the spatter cone. . Important dates discussed in the text are shown with arrows (our field mission is highlighted with a colored text box).

(c) Application of the Failure Forecast Method using the volumetric magma flux rate as precursory signal during the rapid lava lake elevation periods shown in the insets. 


\section{$\begin{array}{lll}3 & 3 & \text { Insights on a future potential eruptive scenario }\end{array}$}

We have seen, that the current eruptive activity at Nyiragongo displays many common features with those preceding the catastrophic eruptions of 1977 and 2002 (Fig. 2a). To push further the comparison and highlight possible scenarios for the evolution of the current activity, if following the same behavior as the two previous cycles, $\quad$ we applied the "Failure Forecast Method" (FFM; Fukuzuno, 1985; Federico et al., 2012) ) to the periods of rapid lava lake level increase ( $\boldsymbol{\varphi} 2$ on Fig. 2e). FFM links the rate of change of a given precursory signal $\Omega$ to its acceleration,

$\frac{d^{2}}{d t^{2}} \Omega=A\left(\frac{d}{d t} \Omega\right)^{\alpha}$

where A and a are empirical constants depending on the rate change with time. When $a>1$, solutions of (Eq. 4) are power laws and present a singularity at a finite time, which can be interpreted as the time of failure. In a practical form the equation can be rewritten as:

$\frac{d}{d t} \Omega(t)=k\left(1-\frac{t}{t_{f}}\right)^{\frac{1}{\alpha-1}}$

where $t_{f}$ is the time of failure, and $\mathrm{k}$ a constant. Here, we consider $\frac{d}{d t} \Omega(t)$ to be the volumetric magma flux rate $Q$, which increases with the reservoir pressure, and thus proportionally to the lava lake volume/elevation (Eq. 3). In the case of volcanic precursors, $\alpha$ is frequently approximately or equal to 2 (Voight, 1988; Kilburn \& Voight, 1998; Hao et al., 2016). This favors a graphical resolution relying on the regression analysis of inverse rate plots: the linear trend intersects the time-axis at the estimated time of failure $t_{f}$ (Fig. 3c).

For the 1970-1972 (Fig. 4a) and 1994-1995 (Fig. 4b) periods of fast increase of the elevation of the lava lake, the time of failure $\left(t_{f}\right)$ was estimated in the range $(95 \%$ confidence interval for the linear regression ) of December 1975 - January 1977 and December 1998 - December 2005, respectively. These periods fully overlap the effective date of the lateral flank eruption and subsequent lava lake drainage on January 1977 and January 2002. If we apply this method to the current increase of the elevation of the lava lake since 2016 (Fig. 4c), we get a potential failure of the system in the March 2024 - November 2027 interval (95\% confidence interval for the linear regression), centered on July 2025. Such a long-time delay between the precursory signs of FFM rupture and the occurrence of the latter (7-8 years in our case) is not so unusual in volcanic environments (Kilburn, 2018). This may be directly linked to the 
highly non-linear nature of rock failure that can make the build-up to eruptions last several years (Chouet, 1996; Sparks, 2003).

The application of the FFM to forecast volcanic eruptions is classically associated to rock failure (Kilburn \& Voight, 1998; Boué et al., 2016; Vasseur et al., 2017; Kilburn, 2018) . Despite existing correlations between seismic signals and lava lake level fluctuations reported at Nyiragongo (Barrière et al., 2018), we are aware that linking the elevation of the lava lake to rock failure is not straightforward. If the pressure is expected to reach a plateau in the years preceding flank eruptions (i.e. 1972-1977, 1995-2002, and in the next months to years, Figs. 2e and 3a), the induced stress is not expected to relax. In this situation , any magmatic or tectonic perturbation of the system could lead to rock fracturing and the propagation of a dike possibly leading to a flank eruption, as observed in 1977 and 2002. The active rifting system could be another trigger to the Nyiragongo external eruptive activity. Such a tectonic link has previously been evoked in the N-S trending fault-system leading to the lateral 1977 and 2002 fissure eruptions (Carn, 2002/2003; Komorowski et al., 2002/2003; Poland, 2006; Tedesco et al., 2007; d'Oreye et al., 2011; Wafula, 2011; Wood et al., 2017). A similar dependency on tectonics is also observed at the Erta'Ale volcano where the activity of the lava lake responds to regional magmatic-tectonic activity, rendering subtle perturbations at depth visible more rapidly at the surface (Barnie et al., 2016).

\section{Conclusions}

The forming of the new spatter cone in February 2016 within the summit crater of Nyiragongo volcano has accelerated the elevation rate of the crater floor (P3). This mirrors a pressure increase within the shallow magmatic reservoir that feeds both the lava lake and the spatter cone, both of which contributing to lava piling over P3. For the first time a comparison with previous periods of activity preceding the two historical events of lava lake drainage $(1977,2002)$ has been attempted, showing remarkable similarities with the ongoing activity. Since 2016, the activity is in a phase of fast pressurization of the magma system that could reach a plateau in a few months or years according to numerical simulations, which has successfully accounted for the evolution of the lava lake level over 30 years. At this time, the crater would contain a minimum volume of $16 \mathrm{Mm} 3$ of molten lava. Whatever the magmatic and/or the tectonic trigger of the lava lake drainage at Nyiragongo may be, we stress that the eruptive activity could soon enter into a phase where the equilibrium of the system is precarious and where any perturbation of the system could disrupt it. If the current eruptive activity mirrors that observed for the last two cycles of activity, a potential failure of the system in the time between March 2024 - November 2027 could be a possible scenario. $\quad . F \quad$ ield observations and numerical simulations presented in this study raise major civil protection issues for the upcoming years. We 
strongly encourage the international community and local authorities to be vigilant to the threat of any tectonic/magmatic perturbation that could break the equilibrium in the next years

\section{Acknowledgments, Samples, and Data}

This mission could not be done without the invitation of the Goma Volcano Observatory (OVG), their logistic help and their information provided on the activity of Nyiragongo volcano. MONUSCO is warmly thanked for providing a crucial support in several field deployments by helicopter in areas of unrest that are highly insecure . The ICCN provided logistics inside the National Parc of Virunga and provided full assistance with their very professional rangers in the field. Marc Caillet, Loïc and Melody Favre, and Johann Perrigault are thanked for their priceless support in the logistics of the descent into the crater. We also wish to warmly thank Raphaël Paris, Hervé Sthioul, and Fabien Cruchon for their contributions in the 3D photogrammetry, and Stephan Kolzenburg for his helpful comments on an early version of the manuscript, and the two reviewers, Matthew Patrick and Sébastien Valade for their constructive comments. We also acknowledge the INGV initiative LakeCarb and the French government IDEX-ISITE initiative 16-IDEX-0001 (CAP 20-25). The data presented in this study are available at https://doi.org/10.26037/yareta:4jx4pbkweneg5icpnf6bmxthra.

\section{References}

Anderson, K. R., \& Poland, M. P. (2016). Bayesian estimation of magma supply, storage, and eruption rates using a multiphysical volcano model: Kîlauea Volcano, 2000-2012. Earth and Planetary Science Letters, 447, 161-171. https://doi.org/10.1016/j.eps1.2016.04.029

Anderson, K. R., Johanson, I. A., Patrick, M. R., Gu, M., Segall, P., Poland, M. P., Montgomery-Brown, E. K., \& Miklius, A. (2019). Magma reservoir failure and the onset of caldera collapse at Kilauea Volcano in 2018. Science, 366(6470), eaaz1822. https://doi.org/10.1126/science.aaz1822

Balagizi, C. M., Yalire, M. M., Ciraba, H. M., Kajeje, V. B., Minani, A. S., Kinja, A. B., \& Kasereka, M. M. (2016). Soil temperature and $\mathrm{CO}_{2}$ degassing, $\mathrm{SO}_{2}$ fluxes and field observations before and after the February 29, 2016 new vent inside Nyiragongo crater. Bulletin of Volcanology, 78(9), 64. https://doi.org/10.1007/s00445-016-1055-y

Balagizi, C. M., Kies, A., Kasereka, M. M., Tedesco, D., Yalire, M. M., \& McCausland, W. A. (2018) Natural hazards in Goma and the surrounding villages, East African Rift System. Natural Hazards, 93, 3166. https://doi.org/10.1007/s11069-018-3288-x

Bansal, R. K. (2010). A Textbook of Fluid Mechanics. Firewall Media

Barnie, T. D., Oppenheimer, C., \& Pagli, C. (2016). Does the lava lake of Erta'Ale volcano respond to regional magmatic and tectonic events? An investigation using Earth Observation data. Geological Society, London, Special Publications, 420(1), 181-208. https://doi.org/10.1144/SP420.15 
Barrière, J., d'Oreye, N., Oth, A., Geirsson, H., Mashagiro, N., Johnson, J. B., Smets, B., Samsonov, S., \& Kervyn, F. (2018). Single-Station Seismo-Acoustic Monitoring of Nyiragongo's Lava Lake Activity (D.R. Congo). Frontiers in Earth Science, 6, 82. https://www.frontiersin.org/article/10.3389/feart.2018.00082

Barrière, J., d'Oreye, N., Oth, A., Theys, N., Mashagiro, N., Subira, J., Kervyn, F., \& Smets, B. (2019). Seismicity and outgassing dynamics of Nyiragongo volcano. Earth and Planetary Science Letters, 528. https://doi.org/10.1016/j.epsl.2019.115821

Baxter P., Allard P., Halbwachs, M., Komorowski, J.-C., Woods, A., \& Ancia, A. (2002/2003). Human health and vulnerability in the Nyiragongo Volcano eruption and humanitarian crisis at Goma, Democratic Republic of Congo. Acta Vulcanologica, Istituti Editoriali e Poligrafici Internazionali, Pisa - Roma, 14(12), 2002 and 15(1-2) 2003, 109-114.

Boudoire, G., Brugier, Y.-A., Di Muro, A., Wörner, G., Arienzo, I, Metrich, N., Zanon, V., Braukmüller, N., Kronz, A., Le Moigne, Y., \& Michon, L. (2019). Eruptive activity on the western flank of Piton de la Fournaise (La Réunion Island, Indian Ocean): insights on magma transfer, storage and evolution at an oceanic volcanic island. Journal of Petrology, 5.

Boué, A., Lesage, P., Cortés, G., Valette, B., Reyes-Dávila, G., Arámbula-Mendoza, R., \& Budi-Santoso, A. (2016). Performance of the 'material Failure Forecast Method' in real-time situations: A Bayesian approach applied on effusive and explosive eruptions, Journal of Volcanology and Geothermal Research, 327, 622-633. https://doi.org/10.1016/j.jvolgeores.2016.10.002

Burgi, P.-Y., Minissale, S., Melluso, L., Mahinda, C. K., Cuoco, E., \& Tedesco, D. (2018). Models of the formation of the 29 February 2016 new spatter cone inside Mount Nyiragongo. Journal of Geophysical Research: Solid Earth, 123, 9469-9485. https://doi.org/10.1029/2018JB015927

Burgi, P.-Y., Darrah, T. H., Tedesco, D., \& Eymold, W. K. (2014). Dynamics of the mount Nyiragongo lava lake. Journal of Geophysical Research: Solid Earth, 119, 4106-4122. https://doi.org/10.1002/2013JB010895

Carn, S. A. (2002/2003) Eruptive and passive degassing of sulphur dioxide at Nyiragongo volcano (D. R. Congo): The 17th January 2002 eruption and its aftermath. Acta Vulcanologica, Istituti Editoriali $e$ Poligrafici Internazionali, Pisa - Roma, 14(1-2), 2002 and 15(1-2) 2003, 75-85.

Carr, J. M. R., D’Arcy, B., Diefenbach, et al. (2020). Volcanological applications of unoccupied aircraft systems (UAS): Developments, strategies, and future challenges. Volcanica, 3(1), 67-114. https://doi.org/10.30909/vol.03.01.67114

Chouet, B. A. (1996). Long-period volcano seismicity: its source and use in eruption forecasting. Nature, 380, 309-316.

Cuoco, E., Spagnuolo, A., Balagizi, C., De Francesco, S., Tassi, F., Vaselli, O. \& Tedesco, D. (2013). Impact of volcanic emissions on rainwater chemistry: The case of Mt. Nyiragongo in the Virunga volcanic region (DRC). Journal of Geochemical Exploration 126, 69-79. https://doi.org/10.1016/j.gexplo.2012.11.008. 
Cuoco, E., Tedesco, D., Poreda, R. J., Williams, J. C., De Francesco, S., Balagizi, C., \& Darrah, T. H. (2013). Impact of volcanic plume emissions on rain water chemistry during the January 2010 Nyamuragira eruptive event: Implications for essential potable water resources. Journal of Hazardous Materials, 244245, 570-581. https://doi.org/10.1016/j.jhazmat.2012.10.055

Denaeyer, M. E. (1973). L'éruption du volcan Rugarama en 1971 et ses produits (Nyamuragira, Kivu). Annales de la Société géologique de Belgique. 96(1), 91-103.

https://popups.uliege.be:443/0037-9395/index.php?id=5804

Donnadieu, F., Kelfoun, K., van Wyk de Vries, B., Cecchi, E., \& Merle, O. (2003). Digital photogrammetry as a tool in analogue modelling: applications to volcano instability. Journal of Volcanology and Geothermal Research, 123 (1-2), 161-180. https://doi.org/10.1016/S0377-0273(03)00034-9

d'Oreye, N., Gonzalez, P.J., Shuler, A., Oth, A., Bagalwa, L., Ekstrom, G., Kavotha, D., Kervyn, F., Lucas, C., Lukaya, F., Osodundu, E., Wauthier, C., \& Fernandez, J. (2011). Source parameters of the 2008 BukavuCyangugu earthquake estimated from InSAR and teleseismic data. Geophysical Journal International, 184, 934-994.

Durieux, J. (2002/2003). Volcano Nyiragongo (D.R.Congo): Evolution of the crater and lava lakes from the discovery to the present. Acta Vulcanologica, Istituti Editoriali e Poligrafici Internazionali, PisaRoma, 14(1-2), 2002 and 15(1-2) 2003, 137-144

Dvorak, J. J., \& Dzurisin, D. (1993). Variations in magma supply rate at Kilauea Volcano, Hawaii. Journal of Geophysical Research., 98(B12), 22255-22268. https://doi.org/10.1029/93JB02765

Federico, A., Popescu, M., Elia, G. Fidelibus, C., Internò, G., \& Murianni, A. (2012) Prediction of time to slope failure: a general framework. Environmental Earth Sciences, 66, 245-256. https://doi.org/10.1007/s12665-011-1231-5

Fukuzuno, T. (1985). A method to predict the time of slope failure caused by rainfall using the increase number of velocity of surface displacement. Journal of the Japan Landslide Society, 22(2), 8-14.

Giordano, D., Polacci, M., Longo, A., Papale, P., Dingwell, D. B., Boschi, E., \& Kasereka, M. (2007). Thermo-rheological magma control on the impact of highly fluid lava flows at Mt. Nyiragongo. Geophysical Research Letters, 34. https://doi.org/10.1029/2006GL028459

Gonnermann, H., \& Taisne, B. (2015). Magma Transport in Dikes. In: The Encyclopedia of Volcanoes (Second Edition), Editor(s): Haraldur Sigurdsson, Academic Press, Pages 215-224.

https://doi.org/10.1016/B978-0-12-385938-9.00010-9

Gregg, T. K. P. (2017). Patterns and processes: Subaerial lava flow morphologies: A review. Journal of Volcanology and Geothermal Research,342, 3-12. https://doi.org/10.1016/j.jvolgeores.2017.04.022 
Gudmundsson, A. (2016). The mechanics of large volcanic eruption. Earth Science Reviews, 163, 72. https://doi.org/10.1016/j.earscirev.2016.10.003-93

Hanks, R. W. (1963). The laminar-turbulent transition for fluids with a yield stress. AIChE Journal, 9(3), 306-309. https://doi.org/10.1002/aic.690090307

Hao, S., Liu, C., Lu, C., \& Elsworth, D. (2016). A relation to predict the failure of materials and potential application to volcanic eruptions and landslides. Scientific Reports, 6, 27877. https://doi.org/10.1038/srep27877

Huppert, H. E., \& Hallworth, M. A. (2007). Bi-directional flows in constrained systems. Journal of Fluid Mechanics, 578, 95-112. https://doi.org/10.1017S0022112007004661

Jeffreys, H. (1925). The flow of water in an inclined channel of rectangular section. The London, Edinburgh, and Dublin Philosophical Magazine and Journal of Science,49(293), 793-807. https://doi.org/10.1080/14786442508634662

Kilburn, C. R. J., \& Voight, B. (1998). Slow rock fracture as eruption precursor at Soufriere Hills Volcano, Montserrat. Geophysical Research Letters, 25(19), 3665-3668. https://doi.org/10.1029/98GL01609

Kilburn, C. R. J. (2018). Forecasting Volcanic Eruptions: Beyond the Failure Forecast Method. Frontiers in Earth Science, 6, 133. https://doi.org/10.3389/feart.2018.00133

Komorowski, J.-C., Tedesco, D., Kasereka, M. et al (2002/2003). The January 2002 flank eruption of Nyiragongo volcano (Democratic Republic of Congo): Chronology, evidence for a tectonic trigger, and impact of lava flows on the city of Goma. Acta Vulcanologica, Istituti Editoriali e Poligrafici Internazionali, Pisa - Roma, 14(1-2), 2002 and 15(1-2) 2003, 27-61.

Kolzenburg, S., Giordano, D., Thordarson, T., Höskuldsson, A., \& Dingwell, D. B. (2017). The rheological evolution of the 2014/2015 eruption at Holuhraun, central Iceland. Bulletin of Volcanology, 79, 45. https://doi.org/10.1007/s00445-017-1128-6

Lev, E., \& James, M. R. (2014). The influence of cross-sectional channel geometry on rheology and flux estimates for active lava flows.Bulletin of Volcanology, 76(829).

https://doi.org/10.1007/s00445-014-0829-3

Lev, E., Ruprecht, P., Oppenheimer, C., Peters, N., Patrick, M., Hernández, P. A., Spampinato, L., \& Marlow, J. (2019) A global synthesis of lava lake dynamics. Journal of Volcanology and Geothermal Research, 381, 16-31, https://doi.org/10.1016/j.jvolgeores.2019.04.010

Melnik, O. (2017). Flow rate estimation in a lava tube based on surface temperature measurements. Geophysical Journal International, 208(3), 1716-1723. https://doi.org/10.1093/gji/ggw475 
Minissale, S., Zanetti, A., Tedesco, D., Morra, V., \& Melluso, L. (2019) The petrology and geochemistry of Nyiragongo lavas of 2002, 2016, 1977 and 2017 AD, and the trace element partitioning between melilitite glass and melilite, nepheline, leucite, clinopyroxene, apatite, olivine and Fe-Ti oxides: a unique scenario. Lithos, 332-333, 296-311. https://doi.org/10.1016/j.lithos.2019.02.023

Morrison, A. A., Whittington, A., Smets, B., Kervyn, M. and Sehlke, A. (2020). The Rheology of Crystallizing basaltic lavas from Nyiragongo and Nyamuragira volcanoes, D.R.C. Volcanica, 3(1), 1-28. https://doi.org/10.30909/vol.03.01.0128

Patrick, M. R., Orr, T., Sutton, A. J., Lev, E., Thelen, W., \& Fee, D., (2016). Shallowly driven fluctuations in lava lake outgassing (gas pistoning), Kilauea Volcano. Earth and Planetary Science Letters, 433, 326338. https://doi.org/10.1016/j.epsl.2015.10.052

Poland, M. (2006). InSAR captures rifting and volcanism in East Africa. Alaska Satellite Facility's News \& Notes, 3, 1-3.

Poland, M. P., Miklius, A., Sutton, A. J., \& Thornber, C. R. (2012), A mantle-driven surge in magma supply to Kîlauea Volcano during 2003-2007. Nature Geoscience, 5(4), 295-300. https://doi.org/10.1038/ngeo1426

Rowland, S. K., \& Walker, G. P. (1990). Pahoehoe and aa in Hawaii: volumetric flow rate controls the lava structure. Bulletin of Volcanology, 52, 615-628. https://doi.org/10.1007/BF00301212

Shoji, S. \& Takahashi, T. (2002). Environmental and Agricultural Significance of Volcanic Ash Soils. Global Journal of Environmental Research, 6, 113-135.

Smets, B., d'Oreye, N., Kervyn, M., \& Kervyn, F. (2017). Gas piston activity of the Nyiragongo lava lake: First insights from a Stereographic Time-Lapse Camera system. Journal of African Earth Sciences, 134, 874-887. https://doi.org/10.1016/j.jafrearsci.2016.04.010

Spampinato, L., Ganci, G., Hernández, P.A., Calvo, D., Tedesco, D., Pérez, N. M., Calvari, S., Del Negro, C., \& Yalire, M. M. (2013), Thermal insights into the dynamics of Nyiragongo lava lake from ground and satellite measurements, Journal of Geophysical Research: Solid Earth, 118, 5771- 5784. https://doi.org/10.1002/2013JB010520

Sparks, R. S. J. (2003). Forecasting volcanic eruptions. Earth and Planetary Science Letters, 210, 1-15. https://doi.org/10.1016/S0012-821X(03)00124-9

Tazieff, H. (1984) Mt. Nyiragongo: renewed activity of the lava lake. Journal of Volcanology and Geothermal Research, 20, 267-280

Tedesco, D. (2002/2003). 1995 Nyiragongo and Nyamulagira activity in the Virunga National Park: A volcanic crisis. Acta Vulcanologica, 14(1-2), 2002 and 15(1-2) 2003, 149-155. 
Tedesco, D., Vaselli, O., Papale, P., Carn, S. A., Voltaggio, M., Sawyer, G. M., Durieux, J., Kasereka, M., \& Tassi, F. (2007). January 2002 volcano-tectonic eruption of Nyiragongo volcano, Democratic Republic of Congo. Journal of Geophysical Research: Solid Earth, 112(B09202.).

https://doi.org/10.1029/2006JB004762

Tedesco, D., Tassi, F., Vaselli, O., Poreda, R. J., Darrah, T., Cuoco, E., \& Yalire, M. M. (2010). Gas isotopic signatures (He, $\mathrm{C}$, and $\mathrm{Ar}$ ) in the Lake Kivu region (western branch of the East African rift system): Geodynamic and volcanological implications. Journal of Geophysical Research: Solid Earth, 115(1), B01205. https://doi.org/10.1029/2008JB006227

Traversa, P., Pinel, V., \& Grasso, J. R. ( 2010). A constant influx model for dike propagation: Implications for magma reservoir dynamics, Journal of Geophysical Research: Solid Earth, 115, B01201, https://doi.org/10.1029/2009JB006559

Valade, S., Ripepe, M., Giuffrida, G., Karume, K., \& Tedesco, D. (2018). Dynamics of Mount Nyiragongo lava lake inferred from thermal imaging and infrasound array, Earth and Planetary Science Letters, 500, 192-204. https://doi.org/10.1016/j.eps1.2018.08.004

Vasseur, J., Wadsworth, F. B., Heap, M. J., Main, I. G., Lavallée, Y., Dingwell, D. B. (2017).

Does an inter-flaw length control the accuracy of rupture forecasting in geological materials? Earth and Planetary Science Letters, 475, 181-189. https://doi.org/10.1016/j.eps1.2017.07.011

Voight, B. (1988). A method for prediction of volcanic eruptions. Nature, 332, 125-130.

Wafula, D. M (2011) Impacts of tectonic earthquakes in the Western Rift Valley of Africa on the volcanic activity of Nyiragongo, Virunga Region. Asian Journal of Scientific Research, 4(3), 209-223. https://doi.org/10.3923/ajsr.2011.209.223

Walker, G. P. L. (1991). Structure, and origin by injection of lava under surface crust, of tumuli, "lava rises", "lava-rise pits", and "lava-inflation clefts" in Hawaii. Bulletin of Volcanology, 53, 546-558.

Wood, D. A., Zal, H. J., Scholz, C. A., Ebinger, C. J., \& Nizere, I. (2017). Evolution of the Kivu Rift, East Africa: interplay among tectonics, sedimentation and magmatism. Basin Research, 29, 175-188. https://doi.org/10.1111/bre.12143

Zurek, J., Moune, S., Williams-Jones, G., Vigouroux, N., \& Gauthier, P.-J. (2019). Melt inclusion evidence for long term steady-state volcanism at Las Sierras-Masaya volcano, Nicaragua. Journal of Volcanology and Geothermal Research, 378, 16-28. https://doi.org/10.1016/j.jvolgeores.2019.04.007 